PijPer, A., Neser, M. L. \& Abraham, G. (1956). J. gen. Microbiol. 14, 371-380

\title{
The Wavelengths of Helical Bacterial Flagella
}

\author{
By A. PIJPER AND MADELEINE L. NESER \\ Institute for Pathology, University of Pretoria, South Africa \\ AND G. ABRAHAM \\ Bureau of Standards, Pretoria, South Africa
}

\begin{abstract}
SUMMARY: During normal movement most motile bacteria carry a straight tail, which, when the movement slows, stiffens into helical structures commonly called flagella. The helices of many kinds of bacteria were photographed with a sunlight darkground microscope, and their wavelengths measured. Mean values and standard deviations were calculated for each strain and then for the species. 'Biplicity' (two wavelengths per bacterium, one twice the other) was observed frequently. Each strain appears to have its own constant wavelengths. The wavelength differs in different kinds of bacteria from 0.60 to $5 \cdot 058 \mu$., the distribution over the various species not revealing a distinct pattern nor any obvious correlation with other characteristics. The wavelength is affected by temperature, $\mathrm{pH}$ value, and colloid content of medium. These features, and the effects of drying, make stained preparations useless for measuring.
\end{abstract}

In sunlight dark-ground microscopy most motile bacteria, except spirilla (Pijper, 1949a, 1955c; Pijper, Crocker, van der Walt \& Savage, 1953) and vibrios (Pijper \& Nunn, 1949) during normal forward movement show a fuzzylooking straight tail, as in Pl. 1, fig. 1 (Pijper, 1946, 1949b). As cultures age, and more rapidly in slide-coverslip preparations, these tails stiffen into clearcut rods, or, more frequently into clear-cut helices (Pijper \& Abraham, 1954; Pijper, 1955a; Pijper, Crocker \& Savage, 1955). Pl. 1, figs. 2-4, show the shortest and the longest wavelengths so far found. 'Wavelength', also called 'period' or 'pitch', is distance from crest to crest. Helices in one culture may be of two different wavelengths, one twice the other (Pijper \& Abraham, 1954; Pijper et al. 1955). For this 'doubling' phenomenon the term 'biplicity' was suggested (Pijper, 1955a). Helices often 'link up' lengthwise and 'pack' crosswise, thus forming 'giant-flagella' (Pl. 1, fig. 5). Slight degrees of packing as in Pl. 1, figs. 3 and 6 , do not affect wavelengths.

Reichert (1909), in dark-ground microscopy of colloid-thickened helices, estimated the pitch of these 'screw-like flagella' of Salmonella typhi as $2 \cdot 5 \mu$., those of Proteus vulgaris as $2 \mu$., and those of sarcinas as usually $3 \mu$., occasionally $2 \mu$. or even $1.8 \mu$. Weibull (1949) precipitated shaken-off flagella of one strain each of $\boldsymbol{P}$. vulgaris and Bacillus subtilis with ammonium sulphate and described the wet helices (really giant-flagella) as having a period of $2 \mu$. in Proteus vulgaris and $2.5 \mu$. in Bacillus subtilis, later confirming the value of $2 \mu$. on ten strains of Proteus vulgaris (Weibull, 1950); he concluded that a definite spiral period is a characteristic feature of bacterial flagella. Leifson (1951), working with bacteria dried and stained on slides, got the impression that perhaps the degree of curvature of flagella might be more important than total length. Recently Leifson, Carhart \& Fulton (1955), again using dried flagellastained bacteria, measured one single wavelength of 10 'flagella' of each one $o$ 
75 strains of Proteus and found large differences between otherwise identical strains, in our opinion caused by the drying process. They did not comment on the 'biplicity' discernible even in their dried and distorted preparations. Their suggestion that the proportion of 'curly' and 'normal' flagella (their names for flagella of obviously single and double wavelengths) is affected by $\mathrm{pH}$ value is not borne out by their figures. Peluffo (1953), whose technique gave us numbers of giant-flagella just as easily visible to us in ordinary microscopy as in phase contrast, measured unknown numbers of these structures by phasecontrast microscopy and found values for Pseudomonadaceae, salmonellas, and $\boldsymbol{P}$. vulgaris of about the same order as ours.

We have watched the genesis of the helical structures in a number of different bacteria, and, under standardized conditions, which we found essential, examined them for wavelength and presence of biplicity.

\section{METHODS}

Organisms. We classified our bacteria after Bergey's Manual (1948), applying the diagnostic methods given there. The salmonellas were also classified serologically.

Photomicrography and measurements. When a sufficient number of tails had stiffened into helices as watched under the microscope, they were photographed with the sunlight dark-ground technique described before (Pijper, 1946). Electric lamps were inadequate, at any rate for the finer helices. With a Zeiss apochromat $\times 60$ and a Contax camera the magnification on the film was $\times 300$. For each strain of bacteria at least one full reel of thirty-six pictures was used. As a rule each reel made over 100 photomicrographs of helical structures available for measuring, and as most of them consisted of more than one wavelength, our calculations for each strain usually were based on several hundreds of wave lengths. The exceptions are specially mentioned. For measuring, the negatives were projected downwards in a vertical photographic enlarger with a Zeiss Sonnar 1:2 at a total magnification of $\times 3000$, on to sheets of white paper. The clear-cut helices were traced with a pencil and then measured with vernier calipers allowing $0.1 \mathrm{~mm}$. to be read. Instances of the very regular frequency curves resulting from this technique are shown in Fig. 1. Mean wavelength and standard deviation (S.D.) were calculated from the millimetre values at the magnification of $\times 3000$. To facilitate understanding and comparison we give them here divided by 3 so as to express them in microns $(\mu$.$) . However, we have kept all the decimals so that our original$ figures can be obtained by multiplying by 3 . We do not ascribe accuracy to our figures beyond the second decimal.

\section{RESULTS}

\section{Effect of temperature}

Appliances for heating and cooling the microscope stage described elsewhere (Pijper, $1955 b$ ) were used for measuring helices at wide ranges of temperature. Table 1 shows that wavelengths increased with rises in temperature. The 
naturally shorter wavelengths were less affected by heat than the longer ones. The observations were repeated with similar results. As a rule a fresh preparation was made for each temperature observation and each preparation was left on the stage for at least an hour before photomicrographs were made. We once kept a slide of Bacillus megaterium 7581 first in a refrigerator at $6^{\circ}$ overnight, which shortened the wavelengths. It was then brought to $47^{\circ}$ on the microscope stage and showed a wavelength of $3 \cdot 564 \mu$. (s.D. $0 \cdot 153$ ) (see Table 1). After this it was cooled on the microscope stage to $3^{\circ}$ for $3 \mathrm{hr}$. and

\section{Table 1. Effect of temperature of microscope stage on helical wavelengths}

Wavelengths are given in $\mu$., followed by the standard deviation in brackets. Values recorded are based on at least 100 measurements.

\begin{tabular}{lccc} 
Name of bacterium & \multicolumn{3}{c}{ Temperatures } \\
Salmonella typhi 901 & $\mathbf{3}^{\circ}$ & $16-19^{\circ}$ & $47^{\circ}$ \\
& $2 \cdot 289$ & $\mathbf{2 \cdot 2 9 4}$ & $\mathbf{2 \cdot 4 4 1}$ \\
S. schottmuelleri 3176 & $(0 \cdot 059)$ & $(0 \cdot 065)$ & $(0 \cdot 062)$ \\
& $2 \cdot 234$ & $2 \cdot 267$ & $2 \cdot 381$ \\
Bacillus megaterium 7581 & $(0 \cdot 053)$ & $(0 \cdot 075)$ & $(0 \cdot 052)$ \\
& $3 \cdot 389$ & $3 \cdot 432$ & $3 \cdot 564$ \\
Serratia marcescens 2302 & $(0 \cdot 111)$ & $(0 \cdot 130)$ & $(0 \cdot 153)$ \\
& $0 \cdot 941$ & $0 \cdot 965$ & $0 \cdot 950$ \\
& $(0 \cdot 037)$ & $(0 \cdot 037)$ & $(0 \cdot 032)$
\end{tabular}

photographed again, it then showed a wavelength of $3 \cdot 392 \mu$. (S.D. 0.131), corresponding very closely to the value for a fresh preparation at that same low temperature given in Table 1 as $3 \cdot 389 \mu$. (s.D. 0.111). A preparation of Salmonella schottmuelleri 3176 at $15^{\circ}$ had a wavelength of $2 \cdot 245 \mu$. (s.D. 0.044), and this when brought to $25^{\circ}$ became $2 \cdot 299 \mu$. (s.D. 0.048). Because of these, and other similar findings, we made our further measurements within the temperature range of $16-19^{\circ}$. During the colder months the microscope room stayed between 16 and $19^{\circ}$, during the hot weather ice-water flowing through a small tank clamped to the microscope stage maintained this same range of temperature (Pijper, 1955b).

\section{Effect of $\mathrm{pH}$ value}

By adding hydrochloric acid or sodium hydroxide to cultures before measuring, the $\mathrm{pH}$ values were adjusted as shown in Table 2 . Readings of $\mathrm{pH}$ values were made by indicators and checked with a Beckman $\mathrm{pH}$ meter. The actual values between slide and coverslip probably deviated somewhat from the intended ones; the effect of the platinum loop, the mica slide (mica was used to get a clearer background), the glass coverslip and further growth during examination was not evaluated. The main finding was that wavelengths were shortest at $\mathrm{pH} \mathbf{7 \cdot 0}$, increased alkalinity and acidity increasing the wavelengths (Table 2). As with the effect of heat, the naturally shorter wavelengths were least affected. The results were confirmed by measuring wavelengths on Salmonella typhi 901 suspended in phosphate buffer solutions of $\mathrm{pH} 6.05$ and 
$10 \cdot 0$ (determined with the Beckman $\mathrm{pH}$ meter), and finding the wavelengths $2 \cdot 366 \mu$. (S.D. $0 \cdot 064$ ) and $2 \cdot 353 \mu$. (s.D. $0 \cdot 061$ ) respectively, both values being higher than the values at $\mathrm{pH} 7 \cdot 0$. In a similar experiment at $20-25^{\circ}$ we found a wavelength of $2 \cdot 315 \mu$. (S.D. $0 \cdot 059$ ) at $\mathrm{pH} 6 \cdot 0$, and a wavelength of $2 \cdot 350 \mu$.

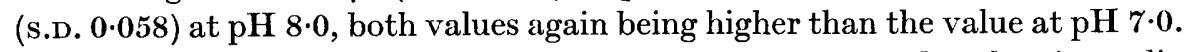
Because of these findings our further measurements were undertaken in media adjusted to $\mathrm{pH} 7 \cdot 0$.

Table 2. Effect of $\mathrm{pH}$ value on helical wavelengths

Values for wavelengths in $\mu$. (based on at least 100 measurements); standard deviation in brackets.

\begin{tabular}{|c|c|c|c|c|c|c|c|c|}
\hline \multirow[b]{2}{*}{ Organism } & \multicolumn{8}{|c|}{ pH values } \\
\hline & $4 \cdot 0$ & $4 \cdot 5$ & $5 \cdot 0$ & $6 \cdot 0$ & $7 \cdot 0$ & $8 \cdot 0$ & $9 \cdot 0$ & $10 \cdot 0$ \\
\hline $\begin{array}{l}\text { Salmonella typhi } \\
901\end{array}$ & - & - & $\begin{array}{c}2 \cdot 336 \\
(0 \cdot 084)\end{array}$ & $\begin{array}{c}2 \cdot 312 \\
(0 \cdot 047)\end{array}$ & $\begin{array}{c}2 \cdot 303 \\
(0 \cdot 051)\end{array}$ & $\begin{array}{c}2 \cdot 367 \\
(0 \cdot 054)\end{array}$ & $\begin{array}{c}2 \cdot 362 \\
(0 \cdot 050)\end{array}$ & $\begin{array}{c}2 \cdot 366 \\
(0 \cdot 065)\end{array}$ \\
\hline $\begin{array}{l}\text { S. schottmuelleri } \\
\mathbf{3 1 7 6}\end{array}$ & $\begin{array}{c}2 \cdot 305 \\
(0 \cdot 059)\end{array}$ & - & $\begin{array}{c}2 \cdot 292 \\
(0 \cdot 044)\end{array}$ & - & $\begin{array}{c}2 \cdot 267 \\
(0 \cdot 051)\end{array}$ & - & $\begin{array}{c}2 \cdot 294 \\
(0 \cdot 050)\end{array}$ & $\begin{array}{c}2 \cdot 284 \\
(0 \cdot 041)\end{array}$ \\
\hline Sarcina ureae & - & - & - & - & $\begin{array}{c}3 \cdot 055 \\
(0 \cdot 100)\end{array}$ & - & $\begin{array}{c}3 \cdot 218 \\
(0 \cdot 074)\end{array}$ & $\begin{array}{c}3 \cdot 323 \\
(0 \cdot 063)\end{array}$ \\
\hline $\begin{array}{l}\text { Proteus mirabilis } \\
3177\end{array}$ & - & $\begin{array}{c}1 \cdot 892 \\
(0 \cdot 092)\end{array}$ & -- & $\begin{array}{c}1 \cdot 874 \\
(0 \cdot 055)\end{array}$ & $\begin{array}{c}1 \cdot 872 \\
(0 \cdot 072)\end{array}$ & $\begin{array}{c}1 \cdot 865 \\
(0 \cdot 059)\end{array}$ & $\begin{array}{c}1 \cdot 861 \\
(0 \cdot 069)\end{array}$ & - \\
\hline
\end{tabular}

\section{Effect of colloid substances}

Colloid substances such as gelatin, gums, agar and methylcellulose when present in bacterial suspensions precipitate on the bacteria and thus coat bodies, tails and helices, making them more readily visible in dark-ground microscopy (Pijper, 1947). We found that the wavelengths of helices, whilst not markedly affected by methylcellulose, were affected by other colloids. Salmonella typhi 901, grown and examined in plain broth, showed a wavelength of $2 \cdot 289 \mu$. (s.D. $0 \cdot 074)$ and in $1 \%(\mathrm{w} / \mathrm{v})$ methylcellulose broth of $2 \cdot 294 \mu$. (s.D. $0 \cdot 065)$. In $10 \%(\mathrm{w} / \mathrm{v})$ gum-arabic broth the wavelength was $2 \cdot 423 \mu$. (s.D. 0.089), and when grown on nutrient agar and suspended in the water of condensation it was $2 \cdot 316 \mu$. (s.D. $0 \cdot 070$ ). S. typhi 2 in plain broth had a wavelength of $2 \cdot 289 \mu$. (s.D. $0 \cdot 053$ ) and in $1 \%$ methylcellulose broth, $2 \cdot 274 \mu$. (s.D. 0.063). Bacillus subtilis 7197 in $1 \%$ methylcellulose broth showed a wavelength of $2 \cdot 157 \mu$. (s.D. $0 \cdot 096$ ) and on agar it was $2 \cdot 277 \mu$. (s.D. 0.042). Because of these findings we subsequently avoided other colloids and used methylcellulose. In a few cases, where no helices appeared in methylcellulose broth, agar was used, and this is specially mentioned.

\section{Effect of going rough}

Several of our strains were old and going rough. Prof. Winkler gave us a smooth form of Salmonella dublin and its rough variant. The smooth form was more motile and had longer tails and helices than the rough variant. A total of 179 measurements on the smooth form gave $2 \cdot 355 \mu$. (s.D. 0.066) and 115 measurements on the rough variant gave $2 \cdot 354 \mu$. (s.D. 0.096). Obviously going 
rough did not affect wavelength. Because of the better development of tails and helices in smooth forms, wherever possible, we picked the smoothest colonies of our strains. Arena \& Schwartz (1937), in stained preparations, saw fewer flagella in rough $S$. typhi than in smooth, but the difference in shape which they described and depicted (more 'wider undulations' in the smooth and more 'narrower undulations' in the rough form) evidently were examples of biplicity and not smooth-rough variation, as they thought.

\section{Effect of drying}

Flagella staining is preceded by drying which distorts, dislocates and redistributes the helical structures on the slide (Pijper, 1946). The flagella of Pl. I, fig. 7, were stained by the method of Leifson (1951), and show marked dissimilarity. In such pictures one can pick out some rather regular and matching shapes, and for measuring purposes the temptation to do so is great, but selection is not fair sampling. In our dark-ground photomicrographs all visible helices could be used without selection, as illustrated by Pl. 2, fig. 8 . Fig. 1 shows frequency curves of helical wavelengths for four strains of bacteria. A curve was drawn for each one from dark-ground and from stained picture measurements. The former are symmetrical with very little scatter, the latter are so irregular that mathematical analysis does not seem worth while, and the mean values of the latter would obviously differ greatly from those of the dark-ground technique. Apart from changes caused by drying the effects of changes in $\mathrm{pH}$ value and in temperature during the staining process must be considerable. Because of all this little value can be attached to measurements of stained flagella.

\section{Helical wavelengths of various bacteria}

We give the mean helical wavelength of each strain, and by formal calculation taking into account the number of measurements on each strain, the mean wavelength of the species. There follows a list of the results; the mean wavelengths are given in $\mu$., followed by the standard deviation (s.D.) in brackets.

Salmonella typhi (Pl. 2, fig. 8). Mean wavelengths of twelve strains: $\mathbf{2} \cdot \mathbf{2 7 4}$ $(0 \cdot 063), 2 \cdot 276(0 \cdot 051), 2 \cdot 282(0 \cdot 060), 2 \cdot 288(0 \cdot 067), 2 \cdot 289(0 \cdot 057), 2 \cdot 293(0 \cdot 061)$, $2 \cdot 294(0.065), 2 \cdot 295(0.047), 2 \cdot 299(0.059), 2 \cdot 301 \quad(0.068), 2 \cdot 304(0.056)$, 2.315 (0.050). Overall mean: 2.293 (0.061). Biplicity: in broth culture $S$. typhi 901 once showed 34 helices of mean wavelength $1.106(0.039)$ and in methylcellulose-broth 4 helices averaging $1 \cdot 2 \mu$. (Pl. 2, fig. 9.)

Salmonella paratyphi. Mean wavelengths of six strains: 2.308 (0.083), $2 \cdot 340(0 \cdot 055), 2 \cdot 342(0 \cdot 054), 2 \cdot 367(0 \cdot 077), 2 \cdot 371(0 \cdot 064), 2 \cdot 421(0 \cdot 058)$. Overall mean: $2 \cdot 340(0 \cdot 078)$.

Salmonella schottmuelleri. Mean wavelengths of seven strains: $2 \cdot 252(0 \cdot 068)$, $2 \cdot 267(0.075), 2 \cdot 282(0 \cdot 049), 2 \cdot 298(0 \cdot 046), 2 \cdot 301(0 \cdot 055), 2 \cdot 302(0 \cdot 047), 2 \cdot 335$ $(0 \cdot 061$.) Overall mean: $2 \cdot 289(0.064)$. One strain, 3176, showed abundant biplicity: in one preparation 211 helices of $2 \cdot 267(0.075)$ and 108 helices of 1.131 (0.059). (Pl. 2, fig. 10.) 
Salmonella hirschfeldii. Mean wavelengths of four strains: $2 \cdot 352(0.084)$, $2 \cdot 385(0 \cdot 071), 2 \cdot 409(0 \cdot 070), 2 \cdot 455(0 \cdot 063)$. Overall mean : $2 \cdot 400(0 \cdot 084)$.

Salmonella typhimurium. Mean wavelengths of ten strains: $2 \cdot 267(0 \cdot 073)$, $2 \cdot 287(0 \cdot 056), 2 \cdot 298(0 \cdot 054), 2 \cdot 335(0 \cdot 103), 2 \cdot 344(0 \cdot 063), 2 \cdot 345(0 \cdot 070), 2 \cdot 349$

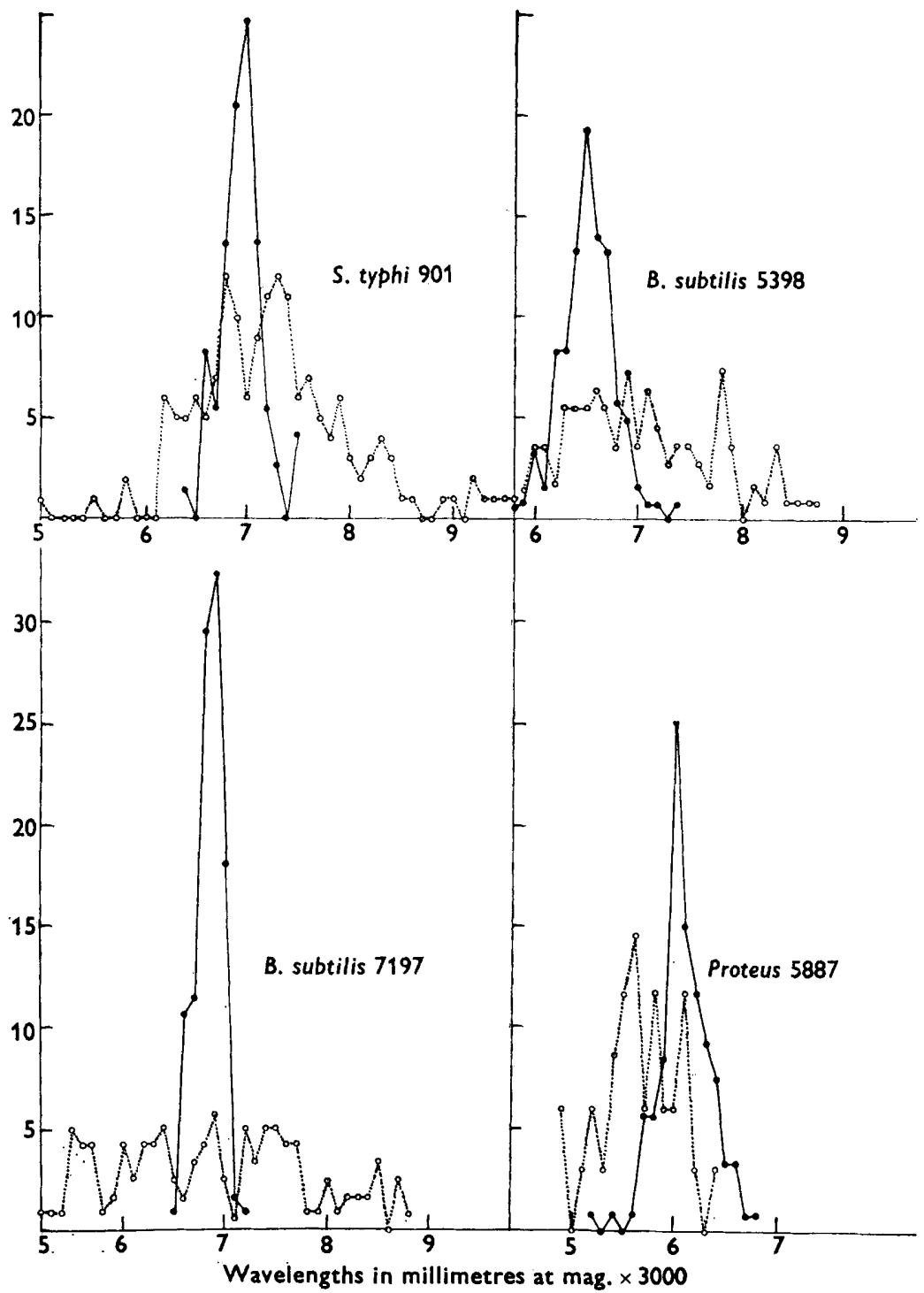

Fig. 1. Frequency curves of wavelengths of helical bacterial flagella. $\bullet-\bullet$, dark ground; 0 - - o, stained.

$(0.084), 2.384(0.081), 2 \cdot 407(0.068), 2.452(0.081)$. Overall mean: $2 \cdot 350$ $(0.091)$. Biplicity: few wavelengths averaging $1 \cdot 2 \mu$. in one strain.

Salmonella enteritidis. Mean wavelengths of three strains: 2.311 (0.109), $2 \cdot 328(0 \cdot 070), 2 \cdot 370(0 \cdot 064)$. Overall mean: $2 \cdot 335(0 \cdot 088)$. 
Salmonella dublin. Mean wavelengths of two local strains from Prof. Henning : $2 \cdot 279(0 \cdot 087)$ and $2 \cdot 280(0 \cdot 087)$. The German strain mentioned above gave $2 \cdot 355(0 \cdot 066)$. Fermentatively the three strains were identical, including action on rhamnose (Kauffmann, 1951).

Proteus mirabilis. Mean wavelengths of nine strains: $1.919(0.066), 1.928$ (0.068), $1.929(0.074), 1.933(0.054), 1.945(0.071), 1.974(0.060), 2.007(0.064)$, $2 \cdot 031(0 \cdot 076), 2 \cdot 031(0 \cdot 086)$. Overall mean: $1.962(0 \cdot 081)$.

Proteus vulgaris. Mean wavelengths of two strains: $2 \cdot 049(0 \cdot 093), 2 \cdot 143$ $(0 \cdot 063)$. Overall mean : 2.098 (0.092). Biplicity: a few helices of average wavelength of about $1 \mu$. (Pl. 2, fig. 11.)

Bacillus megaterium. Mean wavelengths of four strains: $3 \cdot 298(0 \cdot 205)$, $3 \cdot 362(0 \cdot 101), 3 \cdot 432(0 \cdot 130), 3 \cdot 451(0 \cdot 145)$. Overall mean: $3 \cdot 389(0 \cdot 166)$. No biplicity but one strain showed a number of shorter wavelengths averaging 1.1 $\mu$. (Pl. 2, fig. 12, long wavelength.)

Bacillus cereus. Mean wavelengths of eight strains: $2 \cdot 169(0 \cdot 088), 2 \cdot 204$ $(0 \cdot 081), 2 \cdot 255(0 \cdot 075), 2 \cdot 329(0 \cdot 066), 2 \cdot 392(0 \cdot 060), 2 \cdot 479(0 \cdot 095), 2.516(0 \cdot 104)$, $2 \cdot 567(0 \cdot 066)$. Overall mean: $2 \cdot 356(0 \cdot 164)$. Biplicity: the strain of $2 \cdot 169$ showed some wavelengths of about $1 \cdot 2 \mu$. (Pl. 2, fig. 13), and the strains of 2.516 and 2.567 had a number of wavelengths averaging $1 \cdot 3 \mu$.

Bacillus subtilis. Mean wavelengths of eight strains: $2 \cdot 138(0 \cdot 099), \mathbf{2} \cdot 144$ $(0 \cdot 104), 2 \cdot 154(0 \cdot 066), 2 \cdot 157(0 \cdot 096), 2 \cdot 158(0 \cdot 082), 2 \cdot 166(0 \cdot 100), 2 \cdot 229(0 \cdot 060)$, $2 \cdot 295(0 \cdot 080)$. Overall mean: $2 \cdot 186(0 \cdot 103)$. Biplicity: four strains had some wavelengths of about $1 \cdot 1 \mu$.

Bacillus pumilus. Mean wavelengths of six strains: $2 \cdot 333(0 \cdot 122), 2 \cdot 335$ $(0 \cdot 096), 2 \cdot 348(0 \cdot 112), 2 \cdot 349(0 \cdot 123), 2 \cdot 374(0 \cdot 094), 2 \cdot 378(0 \cdot 123)$. Overall mean : $2 \cdot 353(0 \cdot 112)$. Biplicity: one strain had some wavelengths of about $1 \cdot 2 \mu$.

Pseudomonas aeruginosa. Mean wavelengths of three strains: $1 \cdot 477(0 \cdot 048)$, $1.502(0.076)$, $1.552(0.086)$. Overall mean: $1.530(0.086)$. Helices were scanty and the number measured in two strains less than 100 .

Pseudomonas diminuta. Leifson \& Hugh (1954) made this a new species from the very short wavelength of its stained flagella $(0 \cdot 62 \mu$. $)$. We found scanty helices and measured 17 with an average wavelength of $0 \cdot 60 \mu$. (Short wavelength helices are always less affected by outward circumstances) ( $\mathrm{Pl}$. 1, figs. 2, 3).

Pseudomonas of undetermined nature, from retting tank. Mean wavelength of 121 measurements: $\mathbf{1 . 3 4 2}(0 \cdot 075)$.

Azotobacter agile, from local soil. Mean wavelength of 86 measurements: $\mathbf{2 \cdot 0 6 0}(0 \cdot 074)$.

Azotobacter insigne. Mean wavelength of 164 measurements on the strain from Derx (1951) 5.058 (0.157) (Pl. 1, fig. 4).

Aerobacter aerogenes. Mean wavelengths of five strains: 2.247 (0.067), $2 \cdot 285(0.086), 2 \cdot 352(0.085), 2 \cdot 365(0 \cdot 110), 2 \cdot 419(0 \cdot 107)$. Overall mean: $2 \cdot 336(0 \cdot 114)$.

Escherichia coli. Mean wavelength of four strains: $2 \cdot 278(0 \cdot 108), 2 \cdot 315$ $(0 \cdot 101), 2 \cdot 379(0 \cdot 103), 2 \cdot 497(0 \cdot 095)$. Overall mean: $2 \cdot 366(0 \cdot 121)$. Biplicity: two strains had some wavelengths of about $1 \cdot 15 \mu$. 
Serratia marcescens. Mean wavelengths of three strains: $0.965(0.037)$, $2 \cdot 346(0 \cdot 080), 2 \cdot 591(0 \cdot 108)$. The first one produced a variant with a mean wavelength of $0.979(0.050)$. The values are too divergent for an overall mean.

Serratia indica and $S$. kilensis. One strain each with practically identical wavelengths : $2 \cdot 651(0 \cdot 117)$ and $2 \cdot 649(0 \cdot 089)$.

Chromobacterium ianthinum. One strain, producing helices on agar only. Mean wavelength: $1 \cdot 115(0 \cdot 035)$.

Caryophanon latum. One strain, identified by Pringsheim \& Robinow (1947), showed helices on acetate yeast extract medium only. Measurements once done on 84 helices gave a mean of $1.821(0 \cdot 081)$ and on another occasion on 135 helices $1 \cdot 831(0 \cdot 054)$. Biplicity: some wavelengths averaging $0 \cdot 9 \mu$.

Nocardia turbata. Strain received from Dr Dagny Erikson and described by her (1954) produced a number of motile organisms on agar, sometimes branching, often detached. Mean wavelength of 52 helices (Pl. 2, fig. 14): $2 \cdot 500(0 \cdot 125)$.

Sarcina ureae. The mean value previously given (Pijper \& Abraham, 1954) as $3 \cdot 193(0 \cdot 0048)$ was determined in an alkaline medium without regard to temperature; at $\mathrm{pH} 7 \cdot 0$ and temperatures between 16 and $19^{\circ}$ it was 3.055 $(0 \cdot 100)$. Biplicity again was abundant.

\section{DISCUSSION}

We can see no 'pattern' in the distribution of the various wavelengths over the different species, nor is there a correlation between wavelength and other attributes. Three wavelengths were observed in Serratia marcescens and at least two in Pseudomonas spp. Bacillus megaterium and B. cereus both have large diameters, but their wavelengths are very different. Caryophanon latum with its large body has a relatively short wavelength. The salmonellas tended to have wavelengths of about $\mathbf{2 \cdot 3} \mu$., but there seem to be distinct differences between the members of this group, and not all strains of Salmonella dublin had the same wavelength. Biplicity was a varying phenomenon, frequent in some strains and rare or absent in closely allied ones.

Helical wavelengths, however typical in some strains (Pseudomonas aeruginosa and $\boldsymbol{P}$. diminuta, salmonellas in general, Bacillus megaterium, Sarcina ureae, Azotobacter insigne), will be of limited use for classification. There is too much overlapping, the differences are not very great, and there always is a possible latent biplicity. As temperature, $\mathrm{pH}$ value and colloid substances affect wavelengths, accurate measurement is an involved process.

We have witnessed the transition from straight tail to helix in nearly all our bacteria. Exceptions were the pseudomonads, the azotobacters and the nocardia, where we saw no straight tails; perhaps these were too thin. When preparations of these bacteria were left on the stage for some hours, until motility had ceased, helices became visible, though usually in small numbers. Finally, we emphasize that in spirilla there is no transition from straight tail to helix; flagella with a typical twist, which is not helical, are present all the time in spirilla (Pijper, 1955c). 
One of the authors (M.L.N.) was a research assistant under a grant from the Council for Scientific and Industrial Research of the Union of South Africa.

We thank the South African Council for Scientific and Industrial Research for laboratory apparatus and for the services of a research assistant; the National Collection of Type Cultures (London) for most of our cultures; Prof. M. W. Henning, Director of the Salmonella Bureau, Onderstepoort, for several salmonellas and for classifying others; Dr C. G. Crocker (Institute for Pathology, Pretoria), Dr A. Felix (Lister Institute, London), Profs. A. Winkler and E. G. Pringsheim (Göttingen), Dr J. P. van der Walt and Miss C. D. de Kruyff (National S. African Chemical Research Laboratory), Dr D. Erikson (Aberdeen) and Dr E. Leifson (Chicago) for cultures and help in classification; and Miss de Kruyff again for doing the flagella staining.

\section{REFERENCES}

Arena, A. A. \& Schwartz, R. (1937). Coloration des cils par la méthode de Casares Gil. C.R. Soc. Biol., Paris, 124, 500.

Bergey's Manual of Determinative Bacteriology (1948). 6th ed. Ed. by BreEd, R. S., Murray, E. G. D. \& Hitchens, A. P. London: Baillière, Tindall and Cox.

Derx, H. G. (1951). Azotobacter insigne spec.nov., fixateur d'azote à flagellation polaire. Proc. Acad. Sci. Amst. 54, 342.

Erikson, D. (1954). Factors promoting cell division in a 'soft' mycelial type of Nocardia: Nocardia turbata n.sp. J. gen. Microbiol. 11, 198.

Kaufrmann, F. (1951). Enterobacteriaceae, Copenhagen: Munksgaard.

Leifson, E. (1951). Staining, shape, and arrangement of bacterial flagella. J. Bact. 62,377 .

Leifson, E., Carhart, S. R. \& Fulton, M. (1955). Morphological characteristics of flagella of Proteus and related bacteria. J. Bact. 69, 73.

Leifson, E. \& Hugh, R. (1954). A new type of polar monotrichous flagellation. J. gen. Microbiol. 10, 68.

Peluffo, C. A. (1953). Significance of the spiral period of bacterial flagella. Proc. VI Congr. int. Microbiol. 1, 370.

Pijper, A. (1946). Shape and motility of bacteria. J. Path. Bact. 58, 325.

Pijper, A. (1947). Methylcellulose and bacterial motility. J. Bact. 53, 257.

PiJPer, A. $(1949 a)$. The flagella of Spirillum volutans. J. Bact. 57, 111.

Pijper, A. $(1949 b)$. Bacterial surface, flagella and motility. In The Nature of the Bacterial Surface. Symp. Soc. gen. Microbiol. 1, 144.

Pruper, A. (1955 a). Shape of bacterial flagella. Nature, Lond. 175, 214.

PiJper, A. (1955b). Heating and cooling the microscope stage. Amer. J. clin. Path. (in the Press).

PiJPer, A. $(1955 c)$. Flagella and cell wall of spirilla. J. roy. micr. Soc. 75, 38.

PiJper, A. \& Abraham, G. (1954). Wavelengths of bacterial flagella. J. gen. Microbiol. 10,452 .

Pijper, A., Crocker, C. G. \& SAvage, N. (1955). Sarcinae: motility, kind of flagella, and specific agglutination. J. Bact. 69, 151.

Pijper, A., Crocker, C. G., van der Walt, J. P. \& Savage, N. (1953). Flagellum and motility of Spirillum serpens. J. Bact. 65, 628.

Pijper, A. \& Nunn, A. J. (1949). Flagella and motility of Vibrio metschnikovii. J. roy. micr. Soc. 69, 138.

Pringsheim, E. G. \& Robinow, C. F. (1947). Observations on two very large bacteria, Caryophanon latum Peshkoff and Lineola longa (nomen provisorium). J. gen. Microbiol. 1, 267.

ReIchert, K. (1909). Ueber die Sichtbarmachung der Geisseln und die Geisselbewegung der Bakterien. Zbl. Bakt. (1. Abt.), 51, 14.

Weibuld, C. (1949). Morphological studies on salt precipitated bacterial flagella. Ark. Kemi, 1, 21.

Weibuld, C. (1950). Investigations on bacterial flagella. Acta chem. scand. 4, 268. 


\section{EXPLANATION OF PLATES}

All magnifications are $\times 2000$, except Pl. 2, fig. 8 , which is $\times 1000$.

\section{Plate 1}

Fig. 1. Salmonella schottmuelleri 3176.

Figs. 2, 3. Pseudomonas diminuta.

Fig. 4. Azotobacter insigne.

Fig. 5. Giant-flagellum of Salmonella schottmuelleri 3176.

Fig. 6. Giant-flagellum of Bacillus cereus 7464.

Fig. 7. Sarcina ureae stained with Leifson's method for flagella.

Fig. 8. Salmonella typhi 901.

Plate 2

Fig. 9. S. typhi 901, showing biplicity.

Fig. 10. S. schottmuelleri 3176, showing biplicity.

Fig. 11. Proteus vulgaris 4175, showing biplicity.

Fig. 12. Bacillus megaterium $\mathbf{7 5 8 1}$.

Fig. 13. B. cereus 7464, showing biplicity.

Fig. 14. Nocardia turbata.

(Received 27 September 1955) 
Journal of General Microbiology, Vol. 14, No. 2
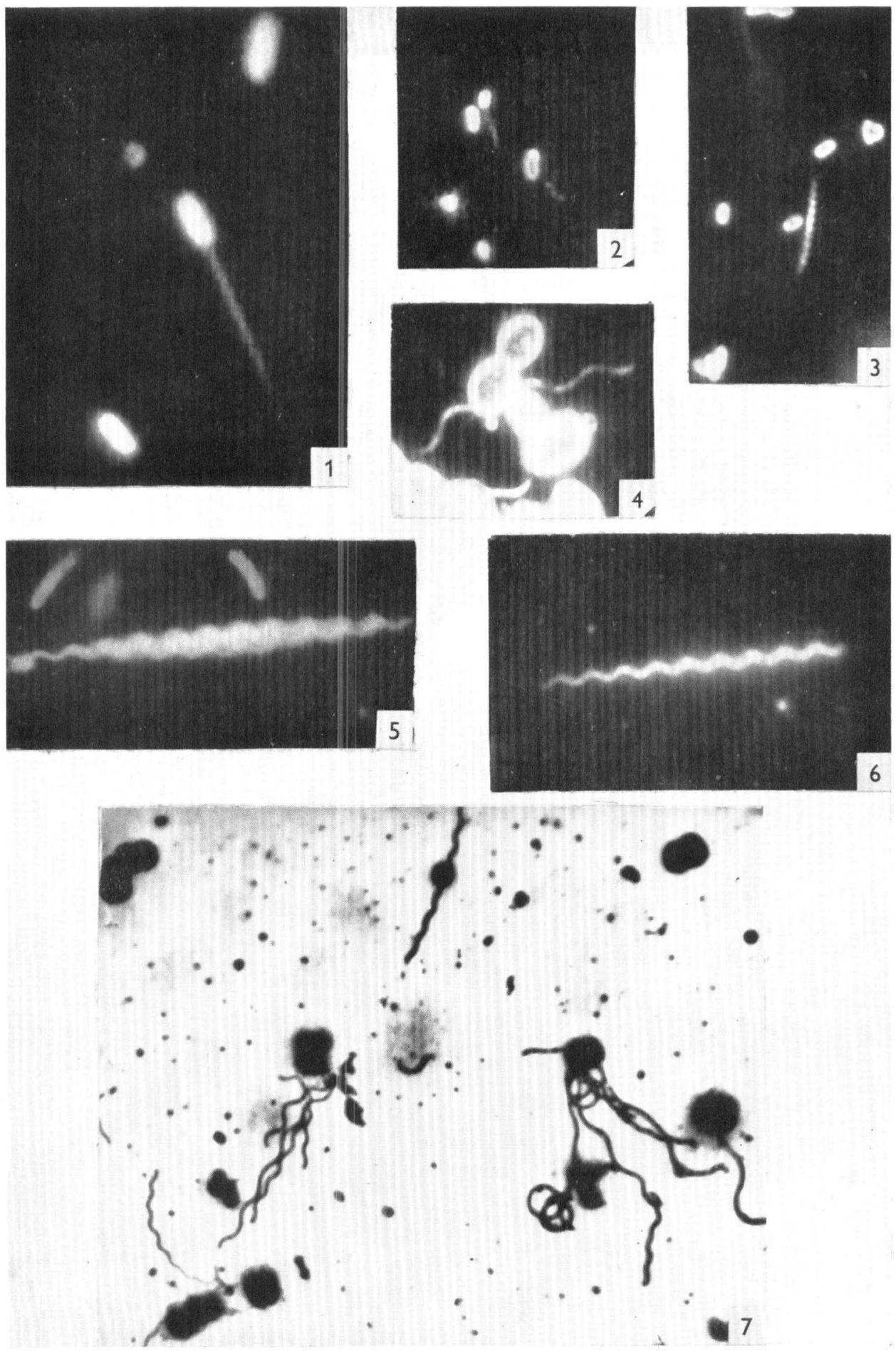

A. Pijper, M. I. Neser \& G. Abraham-Waveingeths of helical bacterial flagella. Plate 1 
Journal of General Micróbiolog̣u, Vol. 14, No. 2
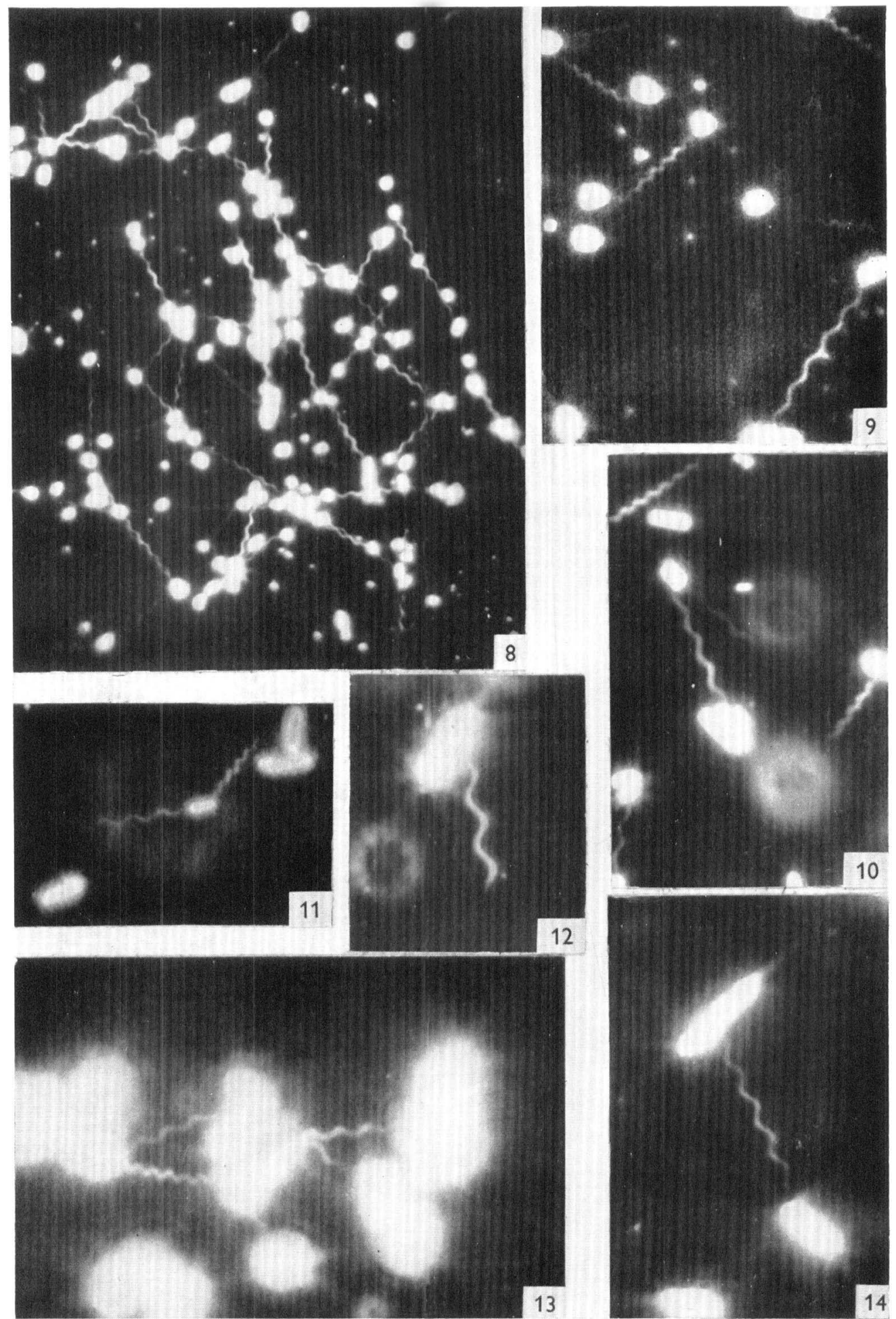

A. Pijpiri, M. L. Nesler \& G. Abraham-Wavelengtis of helical bacterial flagella. PLATL' 2 